\title{
PENINGKATAN KETERAMPILAN BERBICARA BAHASA INGGRIS DENGAN TEKNIK ROLE PLAY PADA SISWA KELAS X SMA DWIJENDRA DENPASAR
}

\author{
Ni Putu Lindawati ${ }^{1}$, Fenny Sengkey ${ }^{2}$ \\ Akademi Komunitas Manajemen Perhotelan Indonesia \\ Badung, Indonesia \\ niputulindawati@yahoo.com¹, fennysengkey@gmail.com²
}

\begin{abstract}
ABSTRAK
Penelitian ini bertujuan untuk mengetahui seberapa besar penggunaan teknik role play dapat meningkatkan keterampilan berbicara peserta didik. Peneliti mengangkat peserta didik kelas X SMA Dwijendra Denpasar sebagai objek penelitian. Penelitian ini berfokus pada keterampilan berbicara khususnya untuk meningkatkan kosa kata sehingga peserta didik mampu dan percaya diri berbicara dengan bahasa Inggris dengan menggunakan teknik role play yang diterapkan pada peserta didik. Landasan teori yang digunakan dalam penelitian ini yaitu teori behavioristik oleh J.B Skinner (1957), keterampilan berbicara oleh Harmer (1983) dan penelitian ini menggunakan pendekatan komunikatif (communicative Approach) yang bertujuan untuk menjadikan kompetensi komunikatif sebagai tujuan pengajaran bahasa serta untuk mengembangkan teknik-teknik pengajaran keterampilan bahasa. Penelitian ini dilaksanakan dalam bentuk penelitian tindakan kelas yang terdiri atas dua siklus dan pada setiap siklus terdiri atas empat tahapan yaitu, perencanaan, pelaksanaan, observasi, dan refleksi.Sebelum dilaksanakan pembelajaran, tes awal diberikan untuk mengetahui kemampuan awal peserta didik dalam kemampuan berbicara sehingga nilai yang diperoleh pada tes awal dapat dibandingkan dengan siklus I dan II setelah diberikan pembelajaran. Hasil dari data kuantitatif menunjukkan bahwa penggunaan teknik role play dapat meningkatkan kemampuan berbicara peserta didik khususnya pada siswa kelas X SMA Dwijendra Denpasar. Hal ini dapat dilihat dari hasil yang diperoleh oleh peserta didik pada saat diberikan tes dan terjadi peningkatan selama teknik role play diterapkan. Nilai rata-rata yang diperoleh peserta didik pada tes awal adalah $46.15 \%$ yang termasuk pada kategori sangat kurang. Setelah diberikan pembelajaran pada siklus I, nilai rata-rata peserta didik meningkat menjadi $70.82 \%$ dengan kategori baik.Pada siklus II nilai rata-rata peserta didik meningkat menjadi $77 \%$ dan tetap berada dalam kategori baik.

Aspek dari kemampuan berbicara yang dijadikan tolak ukur pada penelitian ini yaitu, kosakata, kelancaran, pelafalan tata bahasa, dan pemahaman. Penelitian ini juga didukung oleh data kualitatif.Dari hasil data kualitatif, terbukti bahwa peserta didik mampu berbicara dengan bahasa Inggris ketika berdialog di depan kelas dengan lancar dan menggunakan susunan kalimat yang benar sesuai dengan tata bahasa. Selain itu, peserta didik juga mampu mengucapkan ide-ide yang ada dalam pikiran mereka tanpa malu-malu atau takut salah dalam berbicara dengan rasa percaya diri yang mereka miliki.
\end{abstract}

Kata kunci: kemampuan berbicara, komunikatif, teknik role play

\section{Pendahulan}

Bahasa adalah salah satu alat komunikasi yang sangat penting bahasa digunakan untuk menyampaikan maksud dan tujuan atau sesuatu yang diinginkan oleh seseorang. Setiap negara di dunia memiliki bahasa sebagai identitas negara atau bahasa nasional. Dalam perkembangan di era globalisasi ini, pada akhirnya menuntut hampir semua lapisan masyarakat untuk dapat berbicara dengan menggunakan bahasa internasional yang sudah diakui oleh dunia yaitu bahasa Inggris.

Seseorang yang mampu menguasai keterampilan berbahasa yang baik akan dengan mudah menyerap dan menyampaikan informasi dengan baik. Mata pelajaran bahasa Inggris sebagai 
bahasa kedua atau bahasa asing biasanya telah diberikan sejak dini di sekolah-sekolah.

Pada umumnya, siswa yang telah duduk di tingkat SMP dan SMA masih mengalami kesulitan untuk menyampaikan keinginan, pikiran, dan ide ide yang mereka miliki dengan menggunakan bahasa Inggris. Hal ini juga dialami oleh sebagian besar murid kelas X SMA Dwijendra Denpasar. Fenomena ini disebabkan oleh rendahnya perbendaharaan kata yang dimiliki dan rasa percaya diri siswa kelas $X$ SMA Dwijendra Denpasar, untuk berbicara secara langsung dalam bahasa Inggris. Di sisi lain, faktor yang juga menyebabkan terjadinya hal ini adalah karena kurangnya kreativitas guru dalam menentukan teknik pembelajaran untuk meningatkan keterampilan berbicara bahasa Inggris pada siswa kelas $X$ SMA Dwijendra Denpasar. Pada saat proses belajar mengajar berlangsung, guru cenderung fokus terhadap keterampilan lain, seperti membaca (reading), menulis (writting), dan mendengarkan (listening). Para guru lebih berfokus pada keterampilan tersebut untuk mempersiapkan para siswa saat menempuh ujian nasional di kelas XII nantinya.

Salah satu upaya yang dapat digunakan sebagai alternatif untuk memecahkan masalah tersebut adalah dengan menggunakan teknik "role play". Penggunaan teknik mengajar yang tepat membuat siswa lebih termotivasi dalam belajar bahasa Inggris. Dengan teknik role play, siswa dapat melatih keterampilan berbicara mereka dalam berbagai situasi dan secara tidak langsung, penguasaan kosakata (vocabulary) dalam bahasa Inggris akan lebih banyak.

Berdasarkan uraian pada latar belakang di atas, permasalahan penelitian dapat dirumuskan sebagai berikut: (1) Bagaimanakah keterampilan siswa berbicara dengan bahasa Inggris sebelum menggunakan teknik role play pada siswa kelas X SMA Dwijendra Denpasar?; (2) Bagaimanakah tingkat keterampilan berbicara bahasa Inggris pada siswa kelas $X$ SMA Dwijendra Denpasar sesudah diterapkan teknik role play?; dan (3)
Faktor-faktor apakah yang mempengaruhi peningkatan keterampilan berbicara dalam bahasa Inggris melalui teknik role play pada siswa kelas X SMA Dwijendra Denpasar?

Penelitian ini diharapkan mampu mengetahui penerapan teknik "role play" dalam proses pembelajaran bahasa Inggris untuk meningkatkan kemampuan berbicara. Di samping itu, penelitian ini dilakukan untuk mengetahui tingkat keterampilan berbicara bahasa Inggris pada siswa kelas X SMA Dwijendra Denpasar.

Konsep merupakan ide abstrak yang digunakan untuk memberi klasifikasi atau penggolongan yang pada umumnya dinyatakan dengan suatu istilah atau rangkaian kata (lambang bahasa). Berkaitan dengan semua istilah yang diterapkan, konsep digunakan untuk menghindari kesalahpahaman yang terkait dalam penelitian ini, di bawah ini dipaparkan istilah yang digunakan.

Mengajar adalah segala upaya yang disengaja dalam rangka memberi kemungkinan bagi siswa untuk terjadinya proses belajar-mengajar sesuai dengan tujuan yang ingin dicapai. Dalam proses belajar-mengajar sesuai dengan perkembangannya, guru tidak hanya berperan untuk memberikan informasi terhadap siswa, tetapi lebih jauh guru dapat berperan sebagai perencana, pengatur, dan pendorong siswa agar dapat belajar secara efektif. Peran berikutnya adalah mengevaluasi dari keseluruhan proses belajar-mengajar.

Menurut Harmer (2001:56), konsep mengajar adalah menolong seseorang untuk mempelajari bagaimana melakukan sesuatu, memberi perunjuk, menuntun, memberi ilmu, menyebabkan seseorang mengetahui dan mengerti. Dengan kata lain, mengajar berarti memberikan ilmu atau melatih seseorang.

Peningkatan kemampuan / kompetensi berbahasa merupakan gambaran kemajuan seseorang dalam menghasilkan dan memahami kalimat berdasarkan pengetahuannya. Kompetensi ini terdiri atas dua bagian, yaitu kompetensi linguistik dan komunikasi. Kompetensi linguistik 
merupakan pengetahuan struktur bahasa yang secara tidak sadar dimiliki oleh pembicara dan penuturnya yang ideal.

$$
\text { Hymes (1996) membagi }
$$

pengetahuan tentang bahasa bagi pembicara menjadi 4 kategori yaitu sebagai berikut. (1) Sistematis potensial Proses pembicara dalam suatu sistem untuk menghasilkan banyak bahasa yang potensial. (2) Kecepatan Pembicara mengetahui bahasa yang digunakan sesuai dengan situasi yang tepat. (3) Kejadian/Peristiwa Pembicara mengetahui seberapa sering mengucapkan suatu bahasa. Dengan kata lain, mengetahui dengan benar bahasa tersebut. Semakin banyak mengetahui suatu bahasa, semakin banyak pula pemahaman tentang bahasa tersebut. (4) Kemungkinan terjadi Pembicara mengetahui apakah suatu kemungkinan terjadi dalam bahasa atau tidak. Sistematis potensial bisa saja terjadi diikuti dengan perbaikan seperti "He has been being beaten", tetapi pembicara mengetahui bahwa hal itu tidak mungkin terjadi atau tidak mungkin dalam kehidupan yang nyata. Selain itu, tidak ada aturan untuk mengatakan berapa banyak kata sifat yang kamu harus miliki sebelum kata benda, tetapi dalam beberapa hal pembicara akan mengatakan terlalu banyak tidak masuk akal. Hal ini akan lebih tidak mungkin.

Dengan jelas Hymes menyimpulkan kategori di atas sangat berbeda dengan ide Chomsky, dan idenya sangat lebih kompleks daripada yang dijelaskan di atas. Akan tetapi, apabila pembicara memiliki jalan yang sama untuk mengetahui aturan Hymes, untuk membicarakan dan membuat kemungkinan tidak hanya untuk dirinya dalam memperoleh tata bahasa yang benar, tetapi juga untuk mengatakan "sesuatu yang benar".(Harmer, 1983:1415).

Peningkatan dalam suatu proses meningkatkan kemampuan berbicara bahasa Inggris siswa. Peningkatan merupakan perubahan struktur dan fungsi karakteristik manusia. Perubahanperubahan tersebut terjadi dalam kemajuan yang mantap dan menuju pada suatu kematangan diri melalui interaksi antara potensi bawaan dan potensi lingkungan (Iskandarwassid dan Sunendar 2009:145).

Berbicara merupakan sebuah bentuk penyampaian informasi dengan mempergunakan kata-kata atau kalimat. Dapat juga diartikan bahwa berbicara berarti menggunakan bahasa untuk bermacam-macam bergantung pada para penuturnya. Harmer (1983) menyatakan bahwa berbicara adalah alat komunikasi yang alami antara anggota masyarakat untuk mengungkapkan pikiran dan sebagai sebuah bentuk tingkah laku sosial. Lebih jauh lagi, Harmer (1983) menyatakan bahwa keterampilan berbicara adalah kemampuan menyusun kalimat-kalimat karena komunikasi terjadi melalui kalimat-kaliamat untuk menampilkan perbedaan tingkah laku yang bervariasi dari masyarakat yang berbeda.

Keterampilan berbicara pada hakikatnya merupakan keterampilan mereproduksi arus sistem bunyi artikulasi untuk menyampaikan kehendak, kebutuhan perasaan, dan keinginan kepada orang lain. Keterampilan ini juga didasari oleh kepercayaan diri untuk berbicara secara wajar, jujur, benar, dan bertanggung jawab dengan menghilangkan masalah psikologis seperti rasa malu, rendah diri, ketegangan berat lidah, dan lain-lain.

Berdasarkan pendapat tentang pengertian berbicara yang telah dipaparkan di atas, dapat disimpulkan bahwa pengertian berbicara adalah kemampuan mengucapkan kata-kata untuk menyampaikan atau menyatakan maksud, tujuan, ide, gagasan, pikiran, serta perasaan yang disusun dan dikembangkan sesuai dengan kebutuhan penyimak agar apa yang disampaikan dapat dipahami oleh penyimak atau pendengar.

Kemampuan yang terkait dengan pembelajaran merupakan kecakapan atau kesanggupan seorang siswa untuk menyelesaikan pelajaran yang diberikan oleh guru dan menguasai hal-hal baru yang ingin dipelajari dalam suatu proses belajar mengajar. 
Kemampuan linguistik merupakan pengetahuan struktur bahasa yang secara tidak sadar dimiliki oleh pembicara dan penuturnya secara ideal.

Teknik adalah sebuah cara khas yang operasional, yang dapat digunakan dalam mencapai tujuan yang telah ditetapkan, berpegang pada proses sistematis yang terdapat dalam metode. Oleh karena itu, teknik lebih bersifat tindakan nyata berupa usaha atau upaya yang digunakan untuk mencapai tujuan (Iskandarwassid dan Sunendar 2009:4041).

Role play merupakan suatu teknik pembelajaran yang memberikan kesempatan kepada peserta didik untuk berperan seperti orang-orang yang terlibat atau dalam keadaan yang dikehendaki. Peserta didik berlatih langsung untuk memegang peran sebagai orang lain (Iskandarwassid dan Suhendar 2009:68).

Role play adalah kegiatan berbicara dengan menempatkan diri sebagai orang lain (sesuai peran yang dimainkan). Dalam pembelajaran bahasa Inggris dengan menggunakan teknik role play, guru memiliki peran untuk memberikan kosakata baru pada siswa dan menciptakan situasi belajar yang kondusif sehingga bahasa Inggris dapat digunakan secara nyata dan alami. Selain itu, guru dapat memperbaiki kesalahan berbicara siswa secara langsung dengan menulis di papan tulis sehingga siswa yang lain dapat mengetahui kesalahan tersebut. Rekaman yang digunakan selama percakapan juga dapat digunakan untuk mengetahui bahasa yang mereka pakai sehingga siswa dapat melihat kesalahan umum selama percakapan.

\section{METODE}

Penelitian ini didukung oleh beberapa teori penting. Teori-teori yang digunakan dalam penelitian ini adalah teori behavioristik, teori tata bahasa, dan kosakata.

Pembelajaran terdapat dua aliran, yaitu aliran pembelajaran klasik (behavioristik) dan aliran pembelaran kontemporer (konstruktivisme). Behavioristik adalah peristiwa terbentuknya asosiasi-asosiasi antara peristiwa-peristiwa yang disebut stimulus (S) dan respons $(\mathrm{R})$ yang diberikan atas stimulus tersebut, sedangkan aliran konstruktivisme memandang subjek aktif menciptakan struktur-struktur kognitif interaksi dengan lingkungannya.

Richard (2008:19) menyatakan bahwa penguasaan keterampilan berbicara bahasa Inggris merupakan prioritas utama bagi pembelajar bahasa kedua maupun bahasa asing. Dalam merencanakan kegiatan berbicara untuk pengajaran bahasa kedua maupun bahasa asing, sangatlah penting bagi pembelajar untuk mengenal beberapa fungsi berbicara dalam komunikasi seharihari dan bagaimana pengajarannya.

Terdapat tiga fungsi berbicara yaitu talk as interaction (berbicara sebagai interaksi), talk as transaction (berbicara sebagai transaksi), dan talk as performance (berbicara sebagai penampilan).

Keterampilan

berbicara mensyaratkan adanya pemahaman minimal dari pembicara dalam membentuk sebuah kalimat. Sebuah kalimat, betapa pun kecilnya, memiliki struktur dasar yang saling terkait sehingga mampu menyajikan sebuah makna. Harmer (1983) menyatakan bahwa berbicara merupakan alat komunikasi yang alami antara anggota masyarakat untuk mengungkapkan pikiran dan sebagai sebuah bentuk tingkah laku sosial.

Menurut Cahyono (2013: 27), dalam teori pembelajaran terdapat dua aliran, yaitu aliran pembelajaran klasik (behavioristik) dan aliran pembelaran kontemporer (konstruktivisme). Behavioristik adalah peristiwa terbentuknya asosiasi-asosiasi antara peristiwa-peristiwa yang disebut stimulus (S) dan respons (R) yang diberikan atas stimulus tersebut, sedangkan aliran konstruktivisme memandang subjek aktif menciptakan struktur-struktur kognitif interaksi dengan lingkungannya.

Rancangan program pengajaran untuk mengembangkan keterampilan berbicara dapat memberikan pemenuhan kebutuhan yang berbeda. 
Saat kegiatan berkomunikasi katakata disusun dalam suatu konstruksi yang lebih besar berdasarkan kaidah sintaksis yang ada dalam suatu bahasa. Hal yang penting adalah pengertian yang terkandung di balik kata yang digunakan harus dapat dipahami oleh orang lain sehingga tercipta komunikasi dua arah yang baik dan harmonis.

Apabila seorang pembicara dapat berbicara dengan lancar, maka pendengar akan lebih mudah memahami maksud yang ingin disampaikan. Seringkali pembicara terputus-putus, bahkan antara bagian-bagian yang terputus itu diselipkan bunyi-bunyi tertentu yang mengganggu pemahaman pendengar, misalnya menyelipkan bunyi ee, oo, aa, dan sebagainya.

Apabila seorang pembicara dapat berbicara dengan lancar, maka pendengar akan lebih mudah memahami maksud yang ingin disampaikan. Seringkali pembicara terputus-putus, bahkan antara bagian-bagian yang terputus itu diselipkan bunyi-bunyi tertentu yang mengganggu pemahaman pendengar, misalnya menyelipkan bunyi ee, oo, aa, dan sebagainya.

Dalam pembelajaran bahasa Inggris, pelafalan merupakan salah satu faktor yang mendukung keberhasilan komunikasi lisan. Kesalahan pelafalan dapat menyebabkan terjadinya salah pengertian dan pada akhirnya menyebabkan gangguan komunikasi atau communication breakdown. Dalam kamus Longman Dictionary of Aplied Linguistics (1985:232).

Gebhard (1976:3), seorang ahli bahasa mendefinisikan tata bahasa sebagai suatu kumpulan sistem yang harus dipatuhi oleh pengguna bahasa. Di samping itu, tata bahasa menjadi dasar untuk melahirkan bahasa yang baik dan indah serta menjamin kemantapan bahasa sesuatu bahasa. Menurut Gebhard (1976), tata bahasa berfungsi untuk memisahkan bentuk-bentk bahasa yang gramatis dari yang tidak gramatis.

Pemahaman yang dimaksudkan dalam hal ini merupakan pemahaman dalam suatu topik saat berbicara. Dalam suatu pembicaraan yang formal selalu dituntut persiapan, yang tujuannya adalah untuk dapat benar-benar menguasai topik yang dibicarakan. Jadi, pemahaman sangatlah penting bahkan merupakan faktor utama dalam berbicara.

\section{HASIL DAN PEMBAHASAN}

Penelitian ini dimulai dari permasalahan yang dihadapi oleh siswa dalam keterampilan berbicara (speaking) yang masih rendah. Selanjutnya, diambil sebuah tindakan dengan teknik role play sebagai alternatif dalam meningkatkan kemampuan berbicara bagi siswa kelas $X$ SMA Dwijendra Denpasar.

Model penelitian menggambarkan secara deskriptif alur penelitian yang dilakukan dari tahap teori ke tahap praktis (analisis). Dalam penelitian ini diterapkan Penelitian Tindakan Kelas (PTK).

Instrumen penelitian adalah alat yang digunakan untuk memperoleh data yang diperlukan. Intrumen penelitian yang digunakan berbentuk tes dan non-tes. Instrumen tes digunakan dalam pretest dan posttest. Dalam penelitian ini, digunakan instrumen berupa penugasan untuk membuat percakapan (conversation) yang kemudian dipraktikkan secara berpasangan. Pembelajaran dilakukan dengan pendekatan komunikatif dengan menggunakan teknik role play. Di sisi lain, instrumen non-tes merupakan observasi yang dilakukan dalam penelitian ini yang bertujuan untuk mengetahui keterampilan berbicara bahasa Inggris siswa kelas $X$ SMA Dwijendra Denpasar.

Adapun faktor-faktor yang mempengaruhi peningkatan keterampilan berbicara dalam bahasa Inggris melalui teknik role play pada siswa kelas X SMA Dwijendra Denpasar adalah sebagai berikut.

1. Siswa berusaha dengan giat untuk menguasai lebih banyak kosakata dalam bahasa Inggris agar dapat berdialog dengan lancar ketika maju ke depan kelas.

2. Siswa merespons secara positif kesempatan yang diberikan oleh guru untuk berlatih melafalkan 
kata-kata yang sulit dalam bahasa Inggris,

3. Dengan berdiskusi atau latihan sebelum dialog dilaksanakan, siswa dapat berdiskusi dengan teman-temannya untuk lebih memahami ungkapan, atau katakata yang sulit dipahami saat berdialog,

4. Saat teknik role play berlangsung, siswa berusaha dengan baik untuk memahami dan menguasai kelima aspek peningkatan keterampilan berbicara, yaitu pelafalan, tata bahasa, kosakata, kelancaran, dan pemahaman agar ide-ide yang ingin disampaikan secara lisan pada dialog yang dilakukan di depan kelas dapat dipahami maksud dan tujuan serta maknanya,

5. Motivasi dari sesama siswa untuk dapat menampilkan dialong terbaik, sehingga mereka tidak malu untuk saling bertanya dan memberi tahu.

6. Sarana dan prasarana yang mendukung kegiatan pembelajaran berbicara di sekolah seperti lab bahasa dengan fasilitas yang nyaman dan memadai,

7. Penerapan teknik pembelajaran yang dilakukan oleh guru harus menarik, sehingga dapat meningkatkan semangat siswa dalam kegiatan pembelajaran berbicara.

\section{PENUTUP}

Penelitian tindakan kelas yang dilaksanakan pada penelitian ini telah dapat memecahkan masalah yang dialami oleh siswa kelas $X$ SMA Dwijendra Denpasar dalam bidang meningkatkan keterampilan berbicara bahasa Inggris dengan teknik role play. Sebelum teknik role play diterapkan dalam pembelajaran berbicara bahasa Inggris yaitu, pelafalan, tata bahasa, kosakata, kelancaran, dan pemahaman siswa masih sangat rendah. Para siswa cenderung malu untuk berbicara dengan menggunakan bahasa
Inggris karena takut akan salah dan pada dasarnya penguasaan kosakata (vocabulary) mereka yang masih tergolong sangat kurang. Hal tersebut dapat dilihat pada hasil pretest. Penelitian ini terdiri atas dua siklus, dan tiap siklus terdiri atas dua bagian yaitu latihan dan tes.

Berdasarkan hasil penelitian yang telah dilakukan, dapat disimpulkan bahwa keterampilan siswa dalam berbicara bahasa Inggris pada pelafalan, tata bahasa, kosakata, kelancaran, dan pemahaman meningkat setelah dilaksanakan teknik role play dalam proses pengajaran. Hal tersebut dapat dibuktikan dengan meningkatnya hasil persentase nilai pada pretest ke siklus I dan dari siklus I ke siklus II. Peningkatan persentase nilai rerata siswa dalam pelafalan, tata bahasa, kosakata, kelancaran, dan pemahaman yang terjadi dari pretes dengan nilai $46.15 \%$, pada siklus I mengalami peningkatan menjadi $70.82 \%$, dan pada siklus II mengalami peningkatan menjadi $77.28 \%$.

\section{Saran}

Berdasarkan simpulan diatas, disarankan agar guru dapat menggunakan teknik role play dalam proses pembelajaran speaking karena teknik role play sangat efektif untuk siswa kelas $X$ SMA Dwijendra Denpasar atau SMA lain yang sederajat. Selain itu, disampaikan beberapa saran yang dapat menjadi pertimbangan untuk meningkatkan kemampuan berbicara siswa dengan teknik role play yaiu, sebagai berikut.

1. Pada pelaksanaan teknik role play dalam pembelajaran bicara bahasa Inggris, guru harus dapat meyiapkan topik sesuai dengan level siswa,

2. Guru harus lebih kreatif untuk menyiapkan topik, untuk menghindari adanya topik yang sama,

3. Dalam pelaksanaan teknik role play, guru harus dapat menjelaskan dengan baik tentang tata cara menggunakan teknik role play dalam kegatan berbicara,
4. Teknik role play dapat meningkatkan kemampuan 
berbicara siswa dalam bahasa Inggris.

\section{DAFTAR PUSTAKA}

Cahyono, B. Y. 1997. Pengajaran Bahasa Inggris. Malang: IKIP Malang.

Gebhard, J. 1996. Teaching English as a Foreign or Second Language. United State of America: University of Michigan.

Harmer, J. 1983. The Practice of English Language Teaching, London: Longman.

Harmer, J. 2001. Fourth Edition. The Practice Of English Language Teaching. Cambridge, UK: Pearson Longman.

Iskandarwassid dan Dadang Sunendar. 2009. Strategi Pembelajaran Bahasa. Bandung: PT Remaja Rosdakarya.

Richards, J., Platt, J., Weber, H. 1985 Longman Dictionary of Aplied Linguistics. London: Longman Group Limited.

Richards, J.C. dan Rodgers. 1986. Approaches and Methods in Language Teaching: A Description and Analysis. New York: Cambridge University Press. 